\begin{tabular}{|c|c|c|c|c|}
\hline Star & Mag. & $\Delta \mathrm{RA}$. & $\triangle \mathrm{NPD}$. & Comp. with $*$ \\
\hline$a$ & $9^{1 / 2}$ & $+2^{\mathrm{m}} 5^{\mathrm{s}} \mathrm{10}$ & -. I' $30^{\prime \prime} 8$ & $a^{\prime}$ \\
\hline$b$ & 9 & -422.00 & $\begin{array}{ll}-5 & 49.5\end{array}$ & $b^{\prime}$ \\
\hline$c$ & Io & $-2 \quad 57.55$ & +751.9 & Stone 8897 \\
\hline$c$ & 10 & $--4 \quad 19.75$ & $-0 \quad 52.0$ & Stone 8913 \\
\hline$d$ & $7^{1 / 2}$ & +255.00 & $--4 \quad 54.6$ & Stone 8913 \\
\hline$e$ & 10 & +o 13.10 & +343.1 & $e^{\prime}$ \\
\hline
\end{tabular}

\begin{tabular}{|c|c|c|c|c|}
\hline Star & Mag. & $\Delta \mathrm{RA}$. & $\triangle \mathrm{NPD}$. & Comp. with * \\
\hline$f$ & 10 & $+2^{\mathrm{m}} 32^{5.8} 5$ & $-0^{\prime} 45^{\prime \prime} \cdot 7$ & Stone $906 \mathrm{I}$ \\
\hline$h$ & $9^{1 / 2}$ & +328.30 & - I 55.0 & $g$ \\
\hline$h$ & $9^{1 / 2}$ & $\begin{array}{ll}-4 \quad 2.95\end{array}$ & to 35.5 & $i$ \\
\hline$k$ & 10 & to 15.12 & $-7 \times 0.2$ & $k^{\prime}$ \\
\hline$k^{\prime}$ & $81 / 2$ & to 3.10 & $-7 \quad 40.7$ & Stone 9295 \\
\hline$o$ & I $0^{1 / 2}$ & $-0 \quad 26.90$ & 233.5 & $o^{\prime}$ \\
\hline
\end{tabular}

David Gill.

Beobachtungen des Cometen 1884 II (Barnard).

\begin{tabular}{|c|c|c|c|c|c|c|c|c|}
\hline I 884 & M.Z.Strassb. & $\Lambda \alpha$ & $\Delta \delta$ & $\alpha$ app. & $\log p \cdot A$ & $\delta$ app. & $\log p .4$ & $*$ \\
\hline Oct. I9 & $7^{\mathrm{h}} 31^{\mathrm{m}} 42^{\mathrm{s}}$ & - $0^{\mathrm{m}} 8.43$ & $+3^{\prime} 48{ }^{\prime \prime} 4$ & $21^{\mathrm{h}} 16^{\mathrm{m}} 53^{\mathrm{s}} \mathrm{I}^{8}$ & 8.209 & $-\mathrm{I} 7^{\circ} 3 \mathrm{I}^{\prime} \quad 3^{\prime \prime} 2$ & 0.909 & $\mathbf{I}$ \\
\hline 2 I & $7595^{2}$ & - I $\quad 13.75$ & -0 29.5 & $\begin{array}{lll}21 & 22 & 41.74\end{array}$ & 8.843 & - I $6484^{8} 8.5$ & 0.905 & 2 \\
\hline 23 & $741 \quad 2$ & +2 I 4.43 & +5 I $9 . \mathrm{I}$ & $\begin{array}{lll}21 & 28 & 18.58\end{array}$ & 8.594 & 737.9 & 0.904 & 3 \\
\hline
\end{tabular}

Mittlere Oerter der Vergleichsternefür 1884.0.

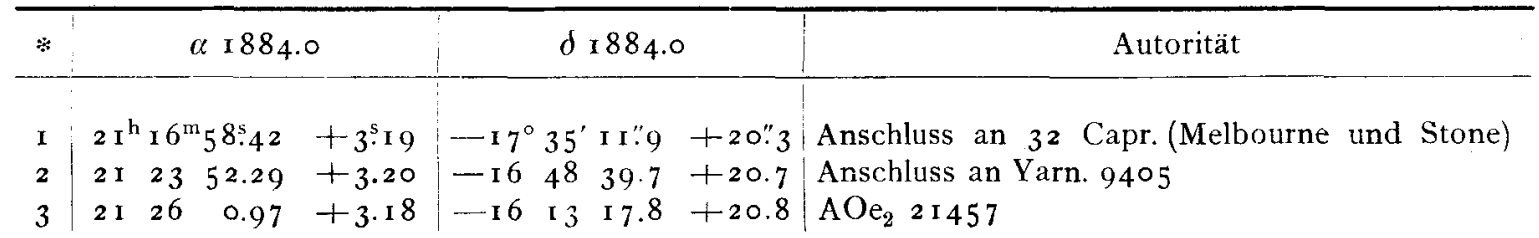

Die Beobachtungen verursachten in den letzten Tagen schon bedeutende Schwierigkeiten, so dass ich nicht sicher bin, ob ich nach Verschwinden des Mondes zu weiteren Beobachtungen im Stande sein werde.

Strassburg 1884 Oct. 3 I.

Wilhelm Schur.

\title{
Approximate elliptic elements of Comet 1884 II (Barnard).
}

I computed a parabolic orbit for this comet in August but was unable to represent the middle place satisfactorily. As a similar result was found in Europe and as Mr. Stechert's ephemeris in Astr. Nachr. Nr. 2609 shewed large discordances from my later observations, I have computed elliptic elements with the following result. The observations used, viz. July 27, August 22 and September 17, were corrected for parallax from the parabolic orbit. The approximations to $Q$ were not carried as far as perhaps they should have been, but the approximation was quite close enough to shew whether the comet was moving in an ellipse and, if so, to give a very fair value of the periodic time.

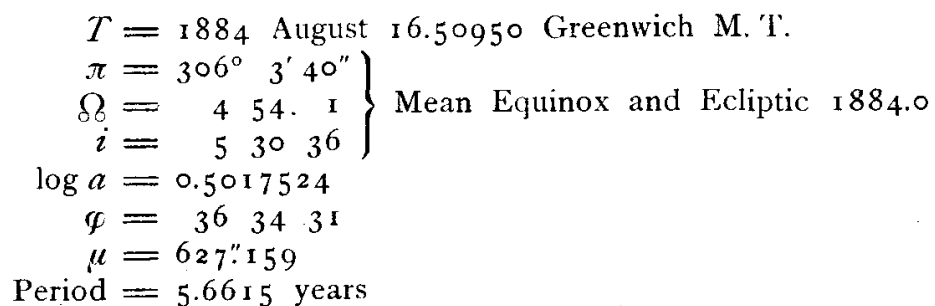

These elements leave a discordance $(\mathrm{C}-\mathrm{O})$ in the middle place of -8 " in longitude and - $\mathbf{I}^{\prime \prime}$ in latitude. The month of October, since the Moon drew away from the evening sky, has been completely clouded until last night Oct. I4, when I secured a fair comparison of the comet with AOe 2 II 5 I. This observation compared with the above elements gives the discordance $(\mathrm{C}-\mathrm{O})$ :

$$
\mathrm{d} \alpha \cos \delta=-5^{\mathrm{s}} \cdot \mathrm{d} \delta=-\mathrm{I} \mathrm{x}^{\prime \prime}
$$

Royal Observatory, Cape of Good Hope $188_{4}$ Oct. 15.

W. H. Finlay. 